УДК 632.954+597.551.2:591[4+8]

А. А. Жиденко

Черниговский государственный педагогический университет им. Т. Г. Шевченко

\title{
ОСОБЕННОСТИ ПЛАСТИЧЕСКОГО ОБМЕНА КАРПА РАЗНОГО ВОЗРАСТА ПОД ДЕЙСТВИЕМ ГЕРБИЦИДОВ
}

\begin{abstract}
Показано вплив різних класів гербіцидів на зміни морфологічних і морфометричних параметрів організму коропа різного віку. Оцінено роль окремих гербіцидів у пластичному обміні, а також можливості формування адаптацій у риб.
\end{abstract}

\author{
A. A. Zhidenko \\ T. G. Shevchenko State Pedagogical University

\section{TRAITS OF CARP'S CONSTRUCTIVE METABOLISM OF DIFFERENT AGES UNDER INFLUENCE OF HERBICIDES}

The paper reveals the influence of different classes of herbicides on changes in morphological and morpho-metric parameters in the carp's organism of different ages. The role of separate herbicides in constructive metabolism and potentialities of the fish adaptation are estimated.

\section{Введение}

В настоящее время в сельском хозяйстве и других отраслях используют большое количество гербицидов, ассортимент и объем производства которых постоянно увеличивается. Гербициды применяют не только для уничтожения сорной растительности на посевах сельскохозяйственных культур, но и для борьбы с зарастанием водохранилищ, прудов, оросительных каналов. Гербициды, попадая в воду, а затем в организм гидробионтов, включаются в метаболизм, могут вызвать нарушения процессов жизнедеятельности и пластического обмена рыб. Известно, что хищники (щука, форель, судак, окунь) и виды, живущие в сильно проточной воде и передвигающиеся на большие расстояния, морфологически мало изменчивы. Наибольшая изменчивость формы тела рыб наблюдается у «мирных» обитателей малопроточных пресноводных водоемов - карпа, карася и некоторых других видов [6]. Кроме того, В. С. Кирпичников, обобщив многочисленные данные по реализуемой наследуемости у карпа экстерьерных индексов, пришел к заключению, что большая часть генов, действующих на форму тела, аддитивна [6]. Цель нашей работы - оценить изменения морфологических и морфометрических параметров карпа разного возраста под действием различных гербицидов, их роль в пластическом обмене и возможность формирования адаптации у рыб.

\section{Материал и методы исследований}

Объектом исследования выбраны мальки, сеголетки и двухлетки карпа (Cyprinus carpio L.), выращенные BAT «Черниговрыбхоз». Опыты по изучению влияния гербицидов проводили в 200-литровых аквариумах, в которые рыбу размещали из расчета 1 экземпляр на 10, 20 или 40 л воды. Длительность эксперимента - 7-14 суток, замену

(C) А. А. Жиденко, 2008 
воды проводили каждые два дня. Во всех случаях осуществляли контроль и поддерживали постоянный гидрохимический режим воды. Величина $p H$ составила 7,60 $\pm 0,28$, содержимое кислорода - 6,5 $\pm 0,5$ мг/л, температура воды соответствовала естественной $\left(+6 \ldots+15^{\circ} \mathrm{C}\right)$. Масса рыб колебалась в пределах 7-13, 40-105 и 150-300 г. Концентрацию исследуемых гербицидов, которая отвечала 2 ПДК (предельно допустимые концентрации), создавали путем внесения рассчитанных количеств 70 \% порошка зенкора, производных дихлорфеноксиуксусной кислоты (2,4-Д) и 36 \% водного раствора раундапа. Для изучения морфометрических характеристик проводили измерения рыб по методическим рекомендациям [2]: $l$ - промысловую длину (до конца чешуйчатого покрова), $H$ - максимальную высоту, $O$ - обхват тела максимальный, $M$ - массу рыбы, $m_{n}-$ массу печени и $m_{c}$ - селезенки. По полученным результатам рассчитывали индексы растянутости, сбитости, массивности, упитанности, коэффициент упитанности, а также индексы печени и селезенки в качестве показателей стресса [15]. Для исследования особенностей пластического обмена определяли процент сухого вещества и воды. Все результаты были обработаны статистически по И. А. Ойвину [9]. Корреляционный анализ и однофакторный дисперсионный анализ проводили согласно методическим рекомендациям [6].

\section{Результаты и их обсуждение}

Для изучения ответной реакции карпа на действие гербицидов были взяты мальки, сеголетки и двухлетки карпа. При лабораторной визуальной оценке морфологических показателей установлено, что изменения наиболее віражены у двухлеток карпа. Они проявляются в появлении геморрагий, язвах на внешних покровах тела, отеке ткани, точечных кровоизлияниях, желтоватой окраске поверхности в области анального отверстия и, в основном, связаны с воздействием раундапа (рис. 1).
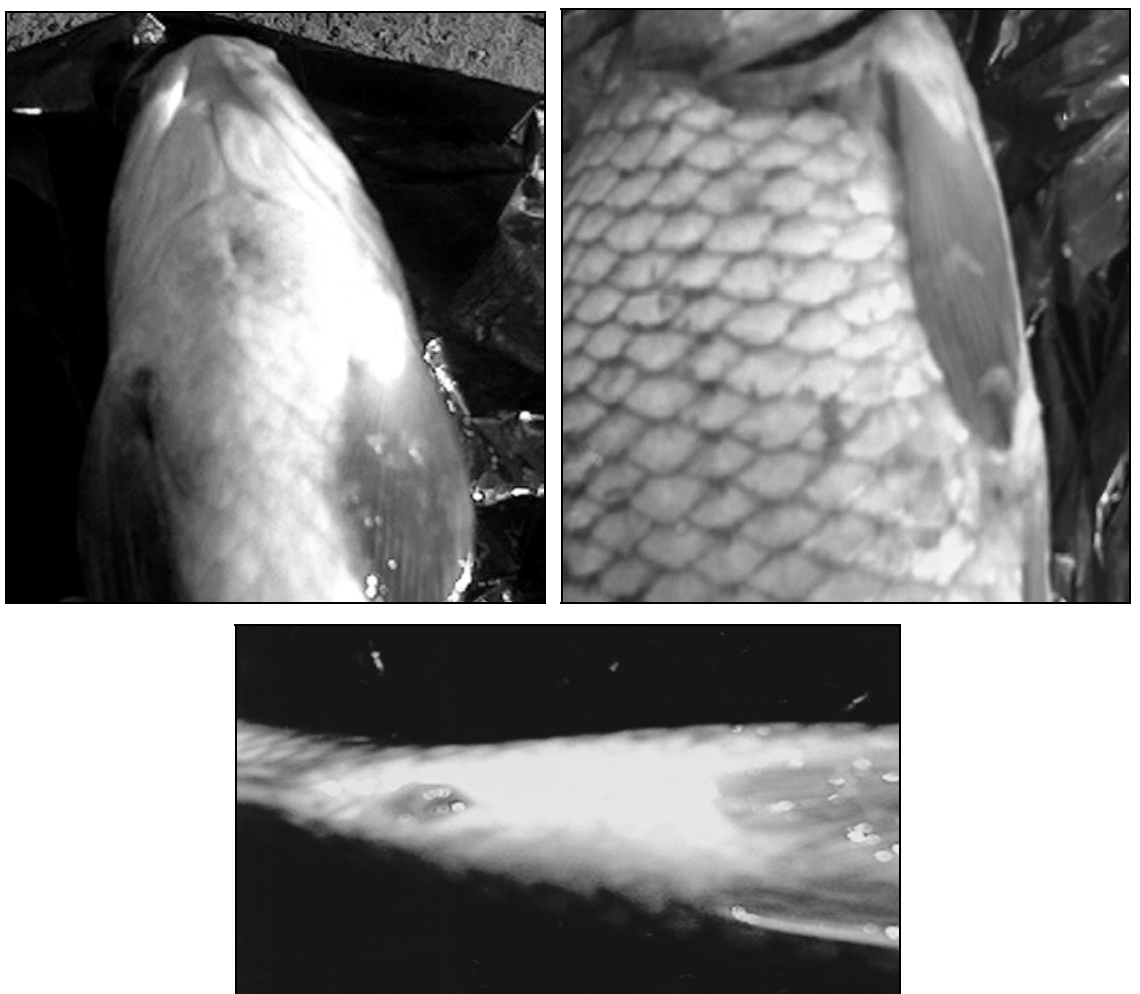

Рис. 1. Изменения внешних покровов тела двухлетки карпа под действием раундапа. 
Поражений внешних покровов тела в условиях гербицидной нагрузки у мальков и сеголеток карпа не наблюдалось. Под действием зенкора и раундапа на грудных и брюшных плавниках двухлеток карпа образуются сетчатые кровоизлияния. Для рыб, находящихся в условиях 2,4-ДА (аминной соли) и 2,4-Д бутилового эфира характерны другие изменения. На чешуе двухлеток карпа появляется беловатая слизь, которая является секретом бокаловидных клеток. Вязкие и клейкие комочки слизевых ниток этих клеток распадаются при попадании в воду, образуя набухшую массу, изменяя цвет и консистенцию воды. Разрушение бокаловидных клеток с выделением большого количества слизи можно рассматривать как срочный этап адаптации, благодаря которому происходит регенерация разрушенной оболочки тела рыб. Поэтому на ее поверхности не образуется изъязвлений, точечных кровоизлияний, отеков и так далее.

Под действием гербицидов, особенно раундапа, тургор мышц карпа снижается, что наиболее характерно для двухлеток. Для проверки визуальной оценки были определены показатели сухого вещества в мышцах (рис. 2).

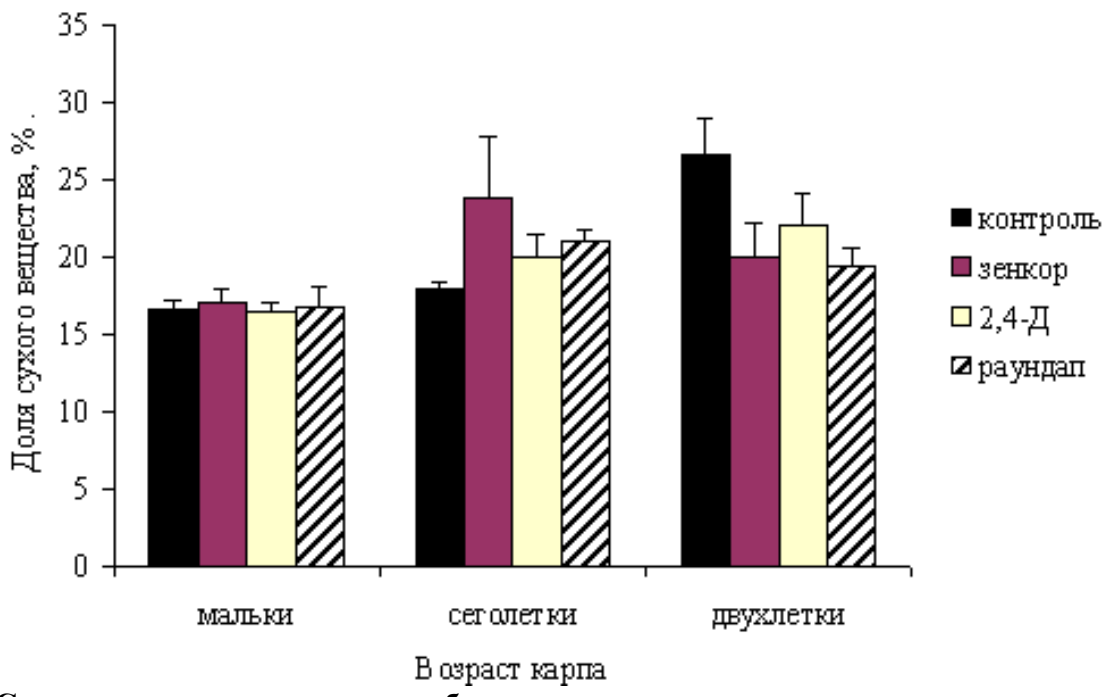

Рис. 2. Содержание сухого вещества в белых мышцах мальков, сеголеток, двухлеток карпа в условиях гербицидной (14 суток) нагрузки, $M \pm m, n=10$.

Под действием гербицидов у мальков процент сухого вещества не изменяется. Для сеголеток характерно увеличение доли сухого вещества и только у двухлеток карпа происходит противоположный процесс (увеличивается процент воды в мышцах). Аналогичное явление установил К. Ф. Сорвачев [13], когда в мышцах Cyprinus carpio L. содержание воды достигло 88 \% в результате трехмесячного голодания при температуpe $+12 \ldots+15^{\circ} \mathrm{C}$. Кроме того, для сеголеток было установлено, что в процессе зимнего голодания при переходе рыб на эндогенное питание количество влаги в мышечной ткани увеличилось с 80,5 \% (октябрь) до 91,3 \% (февраль) [16]. Как известно, в процессе голодания наблюдается значительная деградация клеток мышечной ткани, подчиняющаяся закону “все” или "ничего" [12], происходит снижение содержания нерастворимых белков в мышцах и увеличение - воды. В составе нерастворимых белков мышц рыб находится большое количество глицина, который в свободном виде интенсивнее других аминокислот используется в период зимнего голодания [16]. В нашем эксперименте все вышесказанное относится только к двухлеткам. Доказательством служат изменения массы тела рыб. Эти изменения направлены на поддержание стабильности энергетического обмена, но недостаточны, чтобы существенно повлиять на экстерьер 86 
карпа. Рассматривая возрастной аспект, следует отметить как результат действия гербицидов некоторую лабильность размерно-весовых показателей двухлеток по сравнению с сеголетками и мальками (табл. 1-3), особенно это касается массы тела рыб (см. табл. 1).

Таблий 1

Масса мальков, сеголеток и двухлеток карпа

в условиях гербицидной (14 суток) нагрузки, $M \pm m, n=10$

\begin{tabular}{|l|c|c|c|c|}
\hline \multicolumn{1}{|c|}{ Масса, г } & Контроль & Зенкор & $2,4-Д$ & Раундап \\
\hline Мальки & $10,48 \pm 0,70$ & $12,02 \pm 1,30$ & $10,11 \pm 0,88$ & $9,86 \pm 0,77$ \\
\hline Сеголетки & $57,38 \pm 7,48$ & $66,40 \pm 7,73$ & $55,88 \pm 0,36$ & $49,98 \pm 3,62$ \\
\hline Двухлетки & $309,80 \pm 22,38$ & $242,36 \pm 38,63^{*}$ & $249,50 \pm 47,83^{*}$ & $285,16 \pm 12,96$ \\
\hline
\end{tabular}

Таблица 2

Длина тела мальков, сеголеток и двухлеток карпа

в условиях гербицидной (14 суток) нагрузки, $M \pm m, n=10$

\begin{tabular}{|l|c|c|c|c|}
\hline \multicolumn{1}{|c|}{ Длина тела, см } & Контроль & Зенкор & 2,4 Д & Раундап \\
\hline Мальки & $7,65 \pm 0,24$ & $8,03 \pm 0,39$ & $7,70 \pm 0,21$ & $7,43 \pm 0,19$ \\
\hline Сеголетки & $13,14 \pm 0,53$ & $13,19 \pm 0,51$ & $13,0 \pm 3,21$ & $12,36 \pm 0,47$ \\
\hline Двухлетки & $24,10 \pm 2,11$ & $23,40 \pm 2,22$ & $21,70 \pm 3,24$ & $22,70 \pm 0,42$ \\
\hline
\end{tabular}

Высота тела мальков, сеголеток и двухлеток карпа

Таблица 3

в условиях гербицидной (14 суток) нагрузки, $M \pm m, n=10$

\begin{tabular}{|l|c|c|c|c|}
\hline \multicolumn{1}{|c|}{ Высота тела, см } & Контроль & Зенкор & 2,4 Д & Раундап \\
\hline Мальки & $2,36 \pm 0,14$ & $2,50 \pm 0,05$ & $2,43 \pm 0,09$ & $2,42 \pm 0,07$ \\
\hline Сеголетки & $4,74 \pm 0,18$ & $4,87 \pm 0,17$ & $4,52 \pm 0,12$ & $4,41 \pm 0,13$ \\
\hline Двухлетки & $7,91 \pm 0,51$ & $8,00 \pm 1,22$ & $7,70 \pm 1,24$ & $7,87 \pm 1,42$ \\
\hline
\end{tabular}

Так, у двухлеток карпа под действием зенкора масса тела уменьшилась на $27,8 \%$, под действием $2,4-Д$ - на $24,2 \%$, а под действием раундапа - на $8,6 \%$. Эти данные коррелируют с уменьшением сухого вещества в мышцах двухлеток карпа (рис. 3). Возможно, происходит использование структурных компонентов клетки в катаболитических реакциях для поддержания гомеостаза и энантиостаза рыб. Что касается изменений показателей длины и высоты карпа, то по каждому возрасту отдельно между значениями контрольных и опытных рыб различия не достоверны.

Для уточнения влияния гербицидов на пластический обмен карпа разного возраста рассмотрим накопление исследуемых гербицидов в тканях рыб. О. Б. Мехед установлено [8], что накопление бутилового эфира 2,4-Д кислоты максимально у мальков по сравнению с двухлетками и сеголетками. Высокий уровень кумуляции рыбой 2,4-Д бутилового эфира отмечен также К. К. Врочинским [3]. По литературным источникам [14], зенкор и раундап, в отличие от производных 2,4-Д, обладают слабо выраженными кумулятивными свойствами, поэтому нами в процессе эксперимента по накоплению гербицидов мальками разделение на ткани не производилось. Минимальное накопление было получено для зенкора $(3,98 \pm 0,79)$, выше - для раундапа $(9,73 \pm 1,03$ мг/кг массы рыбы) [4]. Кроме того, согласно теории этапности развития рыб, сформулированной В. В. Васнецовым и дополненной Е. К. Балоном [7], разные структуры организма имеют разный темп роста и дифференцировки на протяжении каждого этапа, но к концу его они уже бывают подготовлены к выполнению новой функции. Это позволяет организму через относительно непродолжительное малоустойчивое состояние быстро достичь устойчивого состояния на следующем возрастном этапе. Развитие организма - 
постепенный и прерывистый (скачкообразный) процесс, причем скорость роста и возможность изменения экстерьера у мальков по сравнению с другими возрастными категориями значительно больше. Для понимания влияния гербицидов на пластический обмен дальнейшие расчеты индексов формы тела проводили только для мальков, так как эти характеристики рыб могут служить показателями пластического обмена. На рисунке 3 отражена динамика индексов: а) сбитости, который определяется по отношению 100 максимальных обхватов тела к длине тела до начала плавниковых лучей; б) массивности (100 максимальных обхватов тела к максимальной высоте тела). Под влиянием гербицидов и на 7-е, и на 14-е сутки наблюдается тенденция к уменьшению этих показателей.

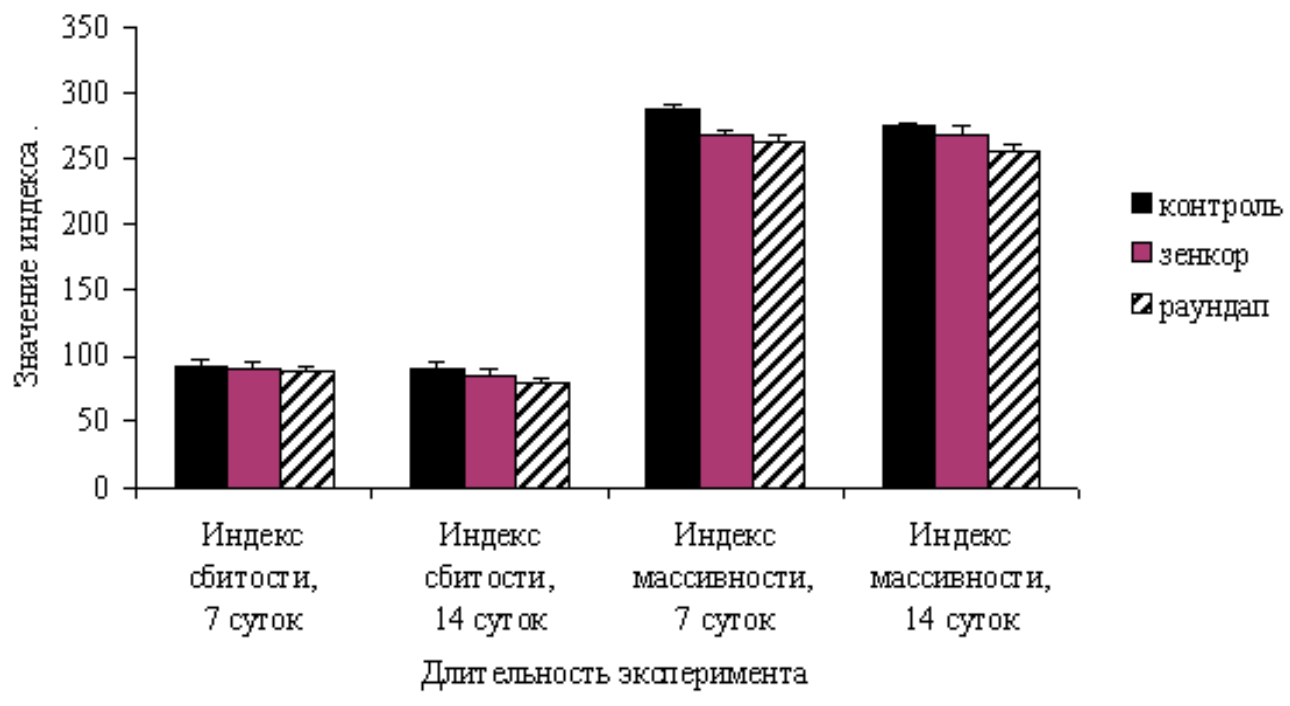

Рис. 3. Динамика индексов сбитости и массивности мальков карпа в условиях гербицидной нагрузки, $M \pm m, n=10$.

Индекс упитанности определяется по формуле $100 \mathrm{M} / \mathrm{HO}$, где $l$ - длина тела, $H$ максимальная высота, $O$ - максимальный обхват тела в см, $M$ - масса тела рыбы вместе с ее внутренностями в г [15]. Существуют два варианта коэффициента упитанности [1]. В первом варианте используется формула Фултона $\left(100 M / l^{3}\right.$, где $M$ - вся масса тела рыбы в $г, l$ - длина тела в см), которая отражает связь упитанности с объемом тела, его плотностью и жирностью. Из общей массы тела $(M)$ не исключается масса гонад и содержимое пищеварительного тракта, которые могут быть значительными, но не имеют отношения к упитанности. Второй вариант - коэффициент, предложенный Ф. Кларк, учитывает массу тела без внутренностей, что необходимо для более точного определения упитанности [1]. В эксперименте мы пользовались формулой Ф. Кларка. Под влиянием гербицидов индексы упитанности мальков на 7-е и на 14-е сутки имеют тенденцию к увеличению, хотя различия в показателях не достоверны (рис. 4). Коэффициенты упитанности мальков и двухлеток практически одинаковы для каждого возраста и только у сеголеток под действием раундапа этот коэффициент возрастает, но тоже недостоверно (рис. 5). Индекс растянутости определяется отношением $100 l$ (длина тела до начала плавниковых лучей) к $H$ (максимальная высота тела рыбы) [15]. Под действием раундапа на 7-е и на 14-е сутки этот индекс возрастает (рис. 6), предположительно за счет большего увеличения длины по сравнению с максимальной высотой тела. Возможным объяснением полученных результатов является участие исследуемых гербицидов в пластическом обмене мальков и сеголеток карпа, поэтому показатели массы не изменяются. 
Индексы селезенки и печени (рис. 7, 8), отражая физиологическое состояние рыбы, относятся к показателям стресса [15]. Величина индекса селезенки (орган образования форменных элементов крови, депо крови и т. д.) в значительной степени зависит от условий обитания рыб в водоемах различной трофности [5]. И. М. Крупень и Л. П. Рыжков связывают увеличение индекса селезенки рыб с возрастанием энергозатрат на обеспечение своей жизнедеятельности при бедной кормовой базе.

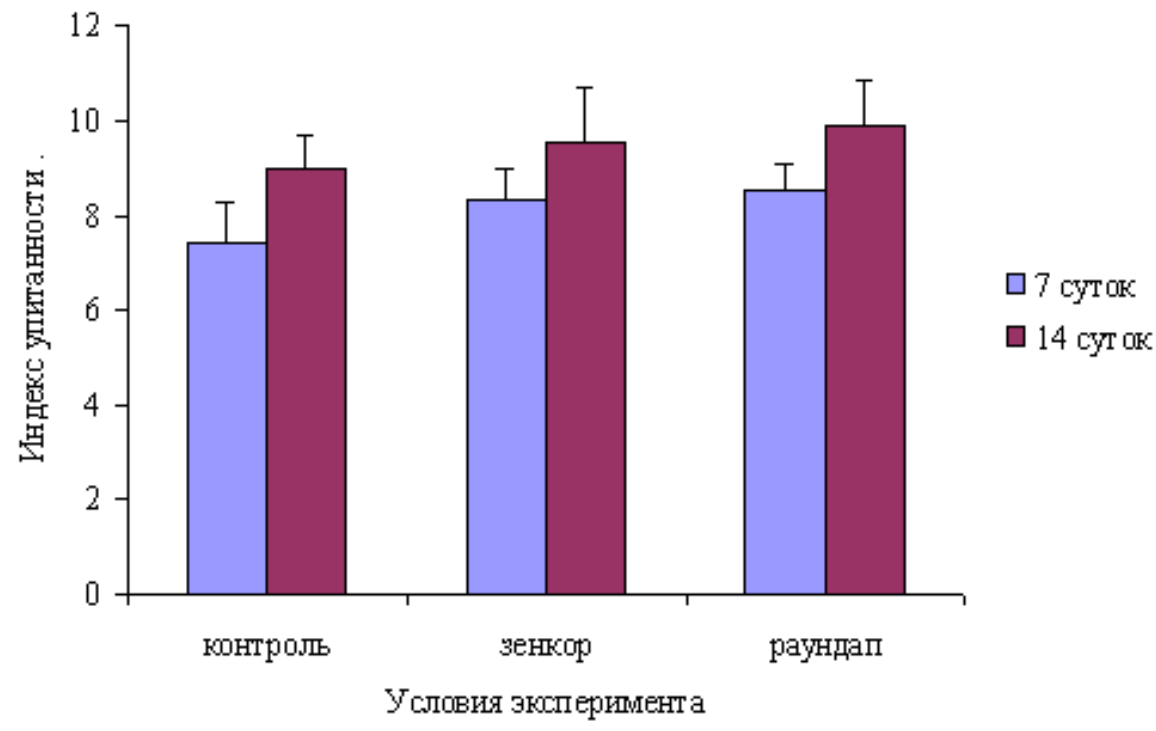

Рис. 4. Динамика индексов упитанности мальков карпа в условиях гербицидной нагрузки, $M \pm m, n=10$.

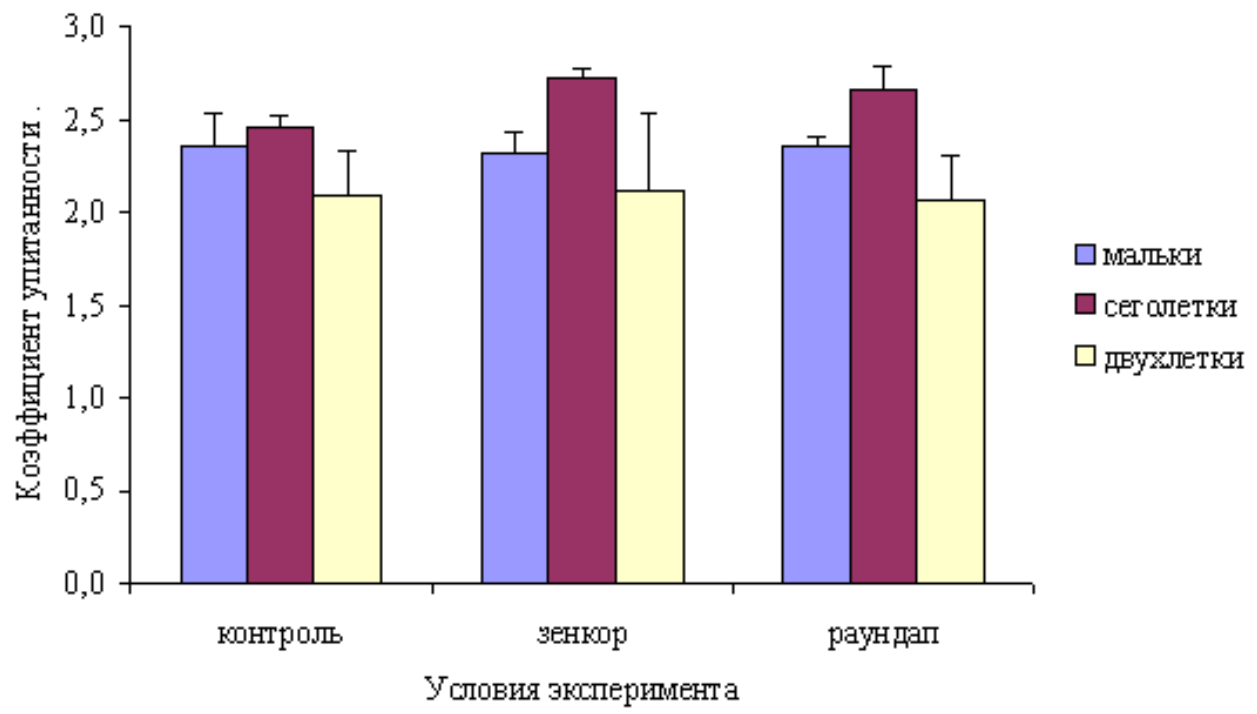

Рис. 5. Коэффициенты упитанности мальков, сеголеток, двухлеток карпа в условиях гербицидной нагрузки (14 суток), $M \pm m, n=10$.

Необходимость больших энергетических затрат на добычу пищи и осуществление жизненных функций приводит к увеличению индекса селезенки рыб [5]. Этими же авторами установлено, что с возрастом происходит уменьшение относительного веса селезенки рыб [10], что не согласуется с нашими результатами (рис. 7,8$)$. Объектом их 
исследований были рыбы (Salmo salar L. morpha sebago Girard - нагульный лосось, возраст 2,1-4,2), обитающие в Онежском озере. Результаты данного эксперимента показали возрастание индекса селезенки у контрольных рыб с увеличением возраста (от мальков к двухлеткам). Под действием гербицидов (дополнительный стрессовый фактор) эти отличия нивелируются. У мальков индекс селезенки уже на 7-е сутки нахождения рыбы в токсических условиях выше, чем у контрольных рыб, а на 14-е сутки под действием зенкора этот показатель больше на $55 \%(p<0,01)$, под действием раундапа также больше на $41 \%(p<0,01)$, что свидетельствует о преобладании анаболитических реакций в организме молоди рыб. У двухлеток - наоборот, происходит уменышение индекса селезенки на 30 и $23 \%(p<0,05)$ соответственно, что доказывает преобладание катаболитических реакций.

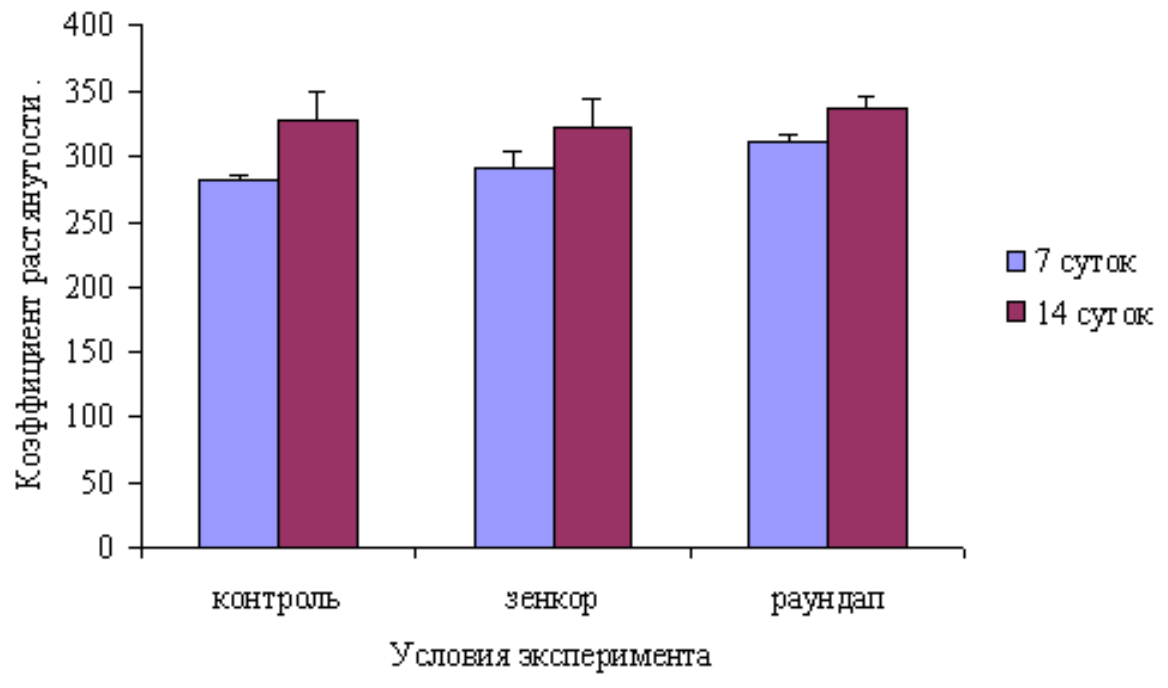

Рис. 6. Динамика индекса растянутости мальков карпа в условиях гербицидной нагрузки, $M \pm m, n=10$.

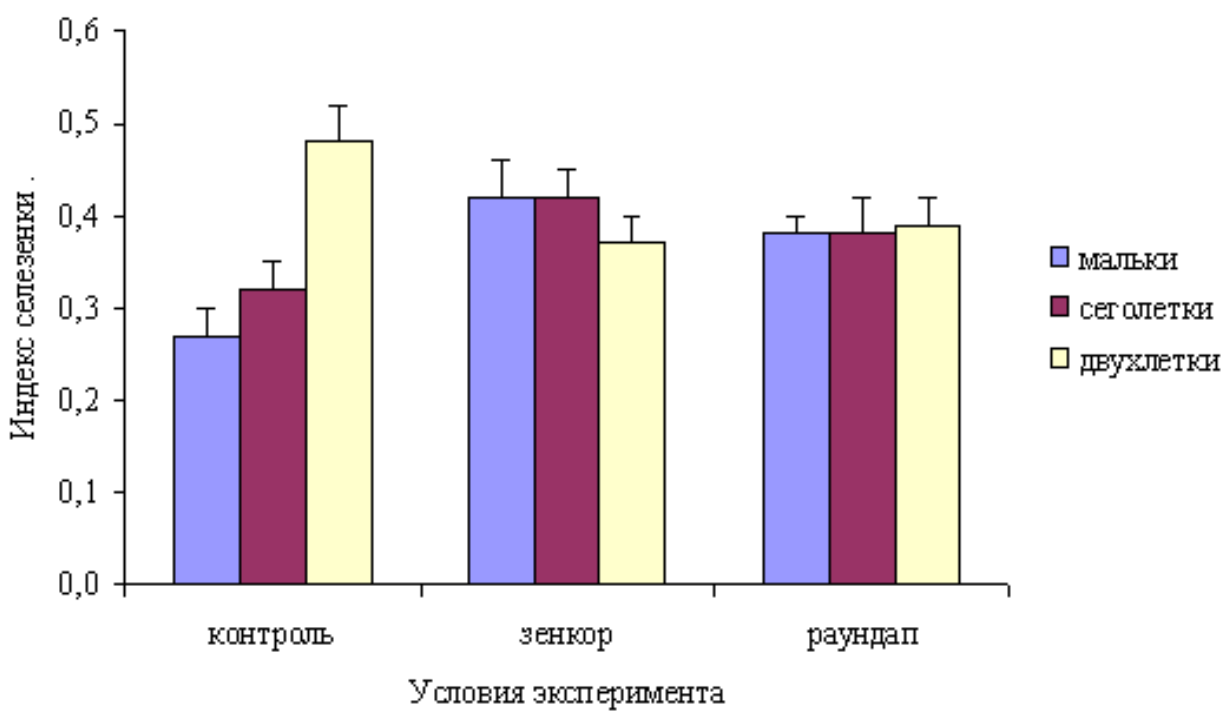

Рис. 7. Индексы селезенки мальков, сеголеток и двухлеток карпа в условиях гербицидной нагрузки (14 суток), $M \pm m, n=6$. 
Разнообразные и сложные функции печени (синтез белков и углеводов, кроветворение, детоксикация, депонирование гликогена и жира и др.) обуславливают лабильность веса и варьирование индекса этого органа. Как показали И. М. Крупень и Л. П. Рыжков, исследовавшие рыб Онежского озера, их высокие энергозатраты не способствуют резервированию питательных веществ в печени рыб [5]. В наших исследованиях индекс печени под действием гербицидов у мальков также возрастает на $49 \%$ (зенкор) и $25 \%$ (раундап). У сеголеток на 14-е сутки эксперимента индексы печени карпов, находящихся в токсических и физиологически нормальных условиях, практически мало отличаются.

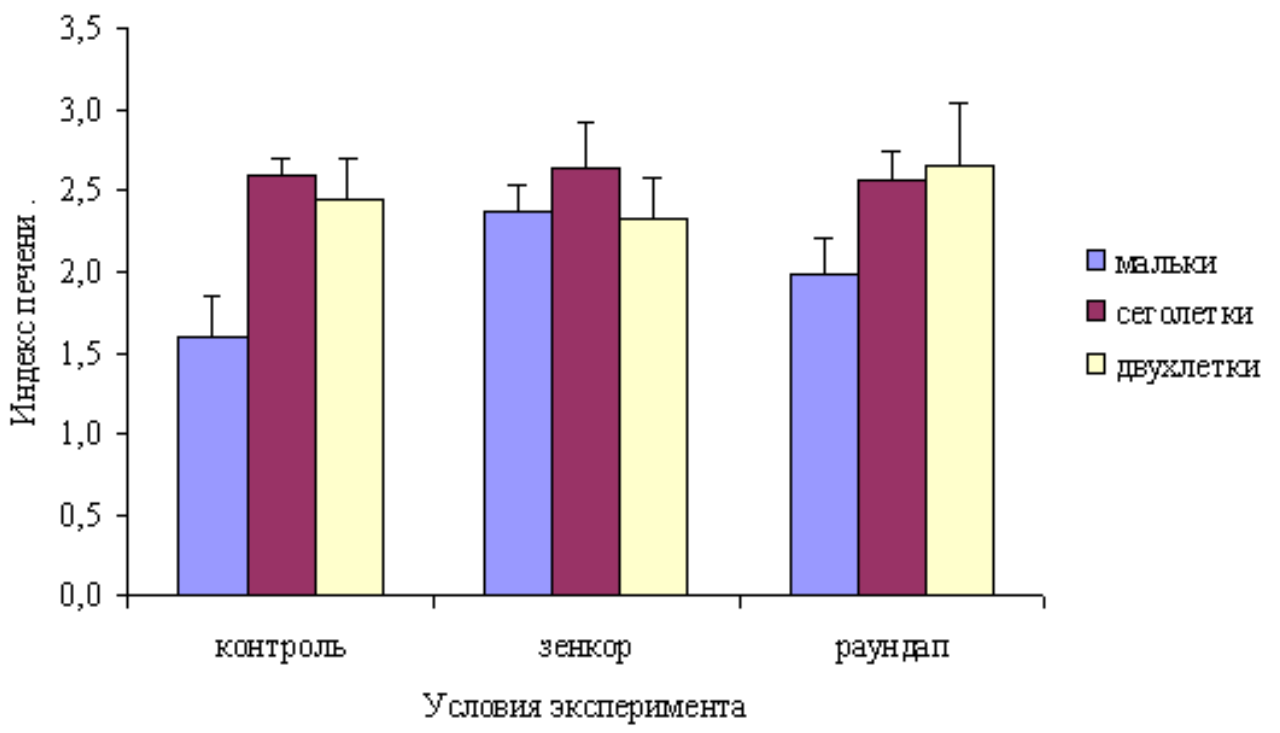

Рис. 8. Индексы печени мальков, сеголеток и двухлеток карпа в условиях гербицидной нагрузки (14 суток), $M \pm m, n=10$.

Можно сделать предварительный вывод о том, что адаптация на морфологическом уровне легче происходит в возрасте одного-двух месяцев. Возможно, это связано с более легким формированием системного структурного следа, переходом срочного этапа адаптации в долговременный, так как именно для этого возраста характерно преобладание анаболитических процессов над катаболитическими. Подтверждением этого служат рассчитанные индексы печени и селезенки в качестве показателей стрессового состояния у карпа разного возраста в условиях гербицидной нагрузки.

\section{Выводы}

Рассматривая возрастной аспект, констатируем, что наиболее негативное влияние гербициды оказывают на двухлеток карпов, что выражается в повреждении внешних покровов тела и уменьшении содержания сухого вещества мышщ (преобладание катаболитических процессов). У мальков на действие гербицидов ответная реакция осуществляется быстрее, что способствует включению гербицидов в их пластический обмен (преобладание анаболитических реакций). Нарушения морфологических показателей у двухлеток карпа наиболее существенны под действием раундапа, что связано с химической природой гербицида и лучшей его растворимостью в воде по сравнению с зенкором и производными 2,4-Д. 


\section{Библиографические ссылки}

1. Анисимова И. М. Ихтиология / И. М. Анисимова, В. В. Лавровский. - М.: Высшая школа, 1983. - 255 с.

2. Баклашова Т. А. Практикум по ихтиологии. - М.: Агропромиздат, 1990. - 223 с.

3. Врочинський К. К. Пестициди і охорона водних ресурсів. - К.: Урожай, 1987. - 160 с.

4. Жиденко А. А. Накопление гербицидов в организме мальков карпа // Сучасні проблеми водних екосистем: Тези доп. Всеукр. наук.-практ. конф. - Д., 2007. - С. 21-22.

5. Кирпичников В. С. Генетика и селекция рыб. - Л.: Наука, 1987. - 520 с.

6. Крупень И. М. Морфофизиологическая индикация нагульного лосося Онежского озера / И. М. Крупень, Л. П. Рыжков // Современные проблемы физиологии и биохимии водных организмов. Матер. Междунар. конф. - Петрозаводск: КНЦ РАН, 2005. - С. 86-91.

7. Лакин Г. Ф. Биометрия. - М.: Высшая школа, 1990. - 352 с.

8. Макеева А. П. Эмбриология рыб. - М.: МГУ, 1992. - 216 с.

9. Мехед О. Б. Накопление гербицидов группы 2,4-Д в организме карпа разного возраста // Гидробиол. журн. - 2006. - Т. 42, № 3. - С. 61-65.

10. Ойвин И. А. Статистическая обработка результатов экспериментальных исследований // Патол. физиол. и экспер. терапия. - 1960. - № 4. - С. 76-85.

11. Рыжков Л. П. Селезенка - морфофизиологический индикатор качественного состояния популяций рыб / Л. П. Рыжков, Т. Ю. Кучко // Экологическая физиология водных организмов. - Петрозаводск: ПетрГУ, 1992. - С. 11-17.

12. Селюков А. Г. Морфофункциональные параметры органов водных рыб - надежные индикаторы состояния экосистем бассейна Оби // Наукові записки Тернопільского націон. пед. ун-ту. Серия: Біологія. - 2005. - № 3 (26). - С. 391-392.

13. Сидоров В. С. Аминокислоты рыб // Биохимия молоди пресноводных рыб. - Петрозаводск: Карел. фил. АН СССР, 1985. - С. 103-137.

14. Сорвачев К. Ф. Основы биохимии питания рыб. - М.: Легк. и пищ. пром-сть, 1982. - 247 с.

15. Справочник по пестицидам: гигиена применения и токсикология / Под ред. А. В. Павлова. - 3-е изд., испр. и доп. - К.: Урожай, 1986. - 432 с.

16. Справочник по физиологии рыб / Под ред. А. А. Яржомбека. - М.: Агропромиздательство, 1986. -192 c.

17. Зависимость выживаемости молоди карпа в условиях зимовки от содержания свободных аминокислот и белков в мышечной ткани рыб / А. Ф. Явоненко, Б. В. Яковенко, В. В. Грубинко, А. А. Жиденко // Рыбн. хоз-во. - 1989. - Вып. 43. - С. 24-29.

Надійшла до редколегії 15.02.2007 